\title{
Consideration of the Future Music Teacher's Performing Skill in the Aspect of Forming His / Her Performing Mobility
}

\author{
Kalishuk Oleksandra \\ ORCID: http://orcid.org/0000-0002-0120-7834 \\ Concertmaster at the Department of Theory and Methods of Voice Production \\ Faculty of Arts named after A. Avdiievskyi \\ Dragomanov National Pedagogical University (Ukraine, Kyiv,)
}

\begin{abstract}
Considered the raising level of performing skills in future Music teacher in the way of forming his performing mobility. The specificity of the instrumental training students is presented and described the various scientific views their professional competence as a teacher and a musician.

Based on teacher observation and analysis of performance practice, the impact skills of improvisation on performing activity of a musician is defined. Disclosed the essence and meaning notion of «improvisation skills» of future Music teacher.

The essence of the peculiarities of the pianist's performance is revealed; structural analysis of its components (information-need, operational-technological, emotional-evaluative and social-communicative) is described. Defined the concepts performing competence and performing activity. Analyzed the abilities of a music teacher to ensure his ability to perform.
\end{abstract}

Keywords: future Music teacher, performing competence, performing mobility, the components of performing mobility.

Актуальність. Динамізм та швидкоплинність сучасних соціальних процесів змінюють умови багатопрофільної та поліфункціональної виконавської діяльності учителя музики, що полягає у синтезі музичного мистецтва та педагогічного впливу на учнів. Це зумовлює необхідність розвитку його здатності до швидкої адаптації щодо змінних умов професійної діяльності та оперативного реагування на ці зміни, а отже, формування його виконавської мобільності $[4 ; 5 ; 6 ; 12 ; 13 ; 14 ; 15]$.

У нашому сьогоденні, щоб бути конкурентноздатним до вимог, які окреслюються для педагога-музиканта закладу загальної середньої освіти (ЗЗСО), треба володіти не тільки високим рівнем професійної компетентності та педагогічної майстерності, але й бути спроможнім до самореалізації, самовдосконалення у своїй професійній діяльності. Через що, специфіка підготовки висококваліфікованого вчителя музики полягає у вихованні одночасно виконавця-музиканта і педагога. За один урок учитель музичного мистецтва в закладі загальної освіти повинен навчати своїх учнів музичної грамоти, сприяти оволодінню учнями навичками слухання музики, розвивати в достатній мірі музичні здібності, співацький голос, ритмічне чуття, надати відомості 
про музичні твори та їх авторів. Педагог-музикант доносить до свідомості слухачівучнів ідеї та художньо-образний зміст музичного твору й авторських засобів музичної виразності. При цьому вчитель музики здійснює словесні пояснення або ставить певні завдання своїм учням. Така діяльність відрізняється від професійної діяльності виконавця-артиста, яка виражається лише в інтерпретації музичного твору без його словесного пояснення.

Виклад основного матеріалу. Українська вчена Г. Падалка називає музичну культуру і педагогічну майстерність основними факторами професійної підготовки майбутніх вчителів музики. Важливо, щоб вчитель музики міг виразно на високому професійному рівні виконувати музичний твір; особливе значення має уміння вчителя образно, цікаво, доступно розповісти учням про музику, дати словесну інтерпретацію музичної образності таким чином, щоб спрямувати сприйняття учнів та пробудити в них любов до музики [8, с. 62].

Професійна підготовка вчителя музики повинна забезпечити можливість його адаптивності до змін соціокультурного середовища. Рівень такої адаптивності залежить від того, як швидко він знайде взаєморозуміння з колегами та учнями, керівниками колективів, а також буде здатним до варіативної зміни діяльності у відповідності до поставлених педагогічних задач. Початком процесу такої адаптації в соціумі буде усвідомлення вчителем того факту, що стереотипи, які були засвоєні в попередній діяльності, не забезпечують досягнення успіху і стають причиною необхідності перебудови поведінки у відповідності до вимог нових соціальних ситуацій. I, коли в процесі діяльності вчителя музики коригуються власні установки, ламаються шаблони та стереотипи, це свідчить про наявність у нього професійної мобільності.

На думку Л. Арчажнікової основою професії учителя музики $є$ синтез педагогіки та музичного мистецтва, які формують його музично-педагогічну діяльність. У процесі вивчення спеціальних дисциплін майбутній вчитель музики набуває таких педагогічних знань та умінь: уміння знайти репертуар та будувати музичний літературний матеріал; володіння виразним мовленням для впливу на учня та пробудження його емоційної сфери; встановлення доцільної манери спілкування 3 учнями; контролювання та здатність об’єктивно оцінювати свої педагогічні дії [1, с. 243]. Такий підхід свідчить про єдність педагогічного та виконавського аспектів 
підготовки майбутнього вчителя музики.

Виконавська компетентність майбутнього учителя музики виступає як сукупність, взаємодія особистісного, когнітивно-діяльнісного та рефлексивного компонентів, ступінь сформованості яких дозволяє йому ефективно здійснювати музично-виконавську діяльність.

Зупинимося на розгляді визначених нами вище компонентів.

Особистісний компонент охоплює музичні здібності, емоційно- вольові якості майбутнього вчителя музики і $є$ провідним компонентом його виконавської компетенції . Особистісний компонент відображає психологічну готовність та здібність майбутнього вчителя до здійснення виконавської діяльності та удосконалення власного досвіду.

Когнітивно-діяльнісний компонент виконує інформаційну, орієнтаційну та трансляційну функції, представляє собою єдність педагогічних, культурологічних, музично- теоретичних та спеціальних знань, а також комплекс умінь, які забезпечують практичну реалізацію виконавської компетентності майбутнього учителя музики.

Рефлексивний компонент містить в собі як критичні, так і евристичні аспекти, виступає як джерело нового знання , виконує регуляторну функцію. Він характеризує здатність до осмислення, самоаналізу та самооцінки майбутнім учителем музики власної музично-виконавської діяльності та її результатів , спроможність до уточнення на підставі власного досвіду оптимальних методів та прийомів роботи над музичним твором [7, с. 45].

Отже, виконавська діяльність являє собою постійний творчий пошук, заснований на діалектичній єдності об'єктивного першоджерела, яке закладено в точному авторському тексті, та суб'єктивного ставлення, пов'язаного 3 творчою ініціативою самого виконавця. Наочним зразком може слугувати опис у наукових доробках Л. Петько створення музичних образів головних персонажів вірша М. Ховітт «The Spider and the Fly» американським композитором і піаністом Вільямом Гіллоком [13, с. 398], акцентуючи увагу на тому, що робота над музичним твором починається 3 розуміння художнього образу і звукового ідеалу твору в цілому та суттєвих у нашому предметі розгляду - образів Павука і Мухи [6, с. 186-187], коли українська піаністка Вікторія Єрмольєва шляхом засвоєння художнього тексту вірша «Паук і Муха», розуміння його головних образів демонструє у своїй творчості «феномен 
метадіалогічності» (багаторівневу міжсуб’єктну взаємодію, що має складну ієрархічну детермінацію і породжує неперервну інтерпретацію текстових структур у різних знакових системах, як особливе свойство музичної свідомості особистості [6, с. 186].

Музичне виконавство, на думку Н. Яранцевої, є одним з найбільш дієвих видів творчої діяльності, так як воно являє собою безпосереднє динамічне спілкування музиканта та слухача. Виконавська діяльність учителя музики $є$ багатопрофільною та поліфункціональною, тому що поєднує багато різноманітних функцій та ролей, які характеризують його функціональність як інструменталіста, вокаліста та хормейстера. Головною якістю такої діяльності є виконавські можливості музиканта, що залежать: від вроджених психологічних, фізіологічних та морфологічних особливостей людини; від набутих знань та умінь, які дозволяють йому ефективно використовувати ці особливості [11, c. 96].

Наголосимо, що виконавська діяльність вчителя музики базується як на основі специфічних технічних навичок, так і на музично-теоретичних знаннях, на вмінні осягнути сенс музичної мови та відтворити його у конкретному звучанні. До особливих якостей вчителя музики в аспекті його виконавської діяльності належить вміння виконувати інструментальні твори різного стилю; вміння розкривати художній образ музичного твору шляхом точного прочитання нотного тексту та власного виконавського досвіду; володіння навичками самостійної роботи над музичним твором; опанування додаткового інструментального репертуару засобом «читання 3 аркушу», знання специфіки виконання репертуару шкільної програми із слухання музики, яке виражається у вмінні виконувати фрагменти творів, акцентувати увагу дітей на найбільш виразних чи значимих моментах; формування та розвиток концертмейстерських навичок: виконання акомпанементу до вокально-хорових та камерно-інструментальних творів; розвиток творчих навичок, що характеризуються імпровізацією, грою «на слух», транспонуванням, створенням нескладних супроводів до пісенного репертуару, аранжування творів та ін. [2, с. 55-56].

Тому, сказане вище дозволяє стверджувати, що виконавська діяльність вчителя музики є інтегрованою властивістю його особистості і характеризується технічними уміннями, здатністю до творчих пошуків у процесі інтерпретації музичних образів. Рівень оволодіння цією діяльністю визначає ступінь підготовленості вчителя музики до 
його професійної роботи в школі.

Для успішної професійної діяльності майбутнього учителя музики йому необхідно не тільки мати професійні знання та уміння. Учитель у процесі своєї виконавської діяльності повинен бути здатним до швидкої адаптації, уміти оперативно реагувати на ті зміни, що відбуваються під час уроку. Розглянемо вказані здібності як якісну характеристику учителя, що забезпечує здатність його швидкого реагування на зміни у сфері виконавської діяльності, тобто виконавську мобільність.

На думку Є. Федоровича, здатність до переключення уваги, iï «гнучкість» формує виконавську мобільність [9, с. 132]. Переключення уваги з одного об'єкта на інший означає свідоме та осмислене їі переміщення. В такому випадку очевидно, що переключення уваги у будь-якій складній ситуації, що швидко змінюється, означає здатність швидко орієнтуватись цій ситуації та визначати або враховувати значимість змін включених в неї елементів. Вміння миттєво переключати увагу дозволяє порівняти свої дії з діями учнів, досягати метроритмічної, артикуляційної, динамічної злагодженості в ансамблі.

Аналіз літературних джерел показав, що дослідженню виконавської мобільності учителя музики у єдності ї складових, що характеризують суть дане поняття, не приділялося достатньої уваги, не було комплексного підходу до розгляду цього питання.

О. Баланко під виконавською мобільністю вважає відкритість музичновиражальної системи виконавця, універсальність професійного потенціалу, здатність кардинально змінювати виконавський арсенал, інтелектуальну рухомість, легкість і швидкість у прийнятті «теоретичних» рішень щодо виконавської техніки як засобу втілення художнього образу музичного твору [2, с. 78]. Особливість виконавської мобільності характеризується сполучуваністю, взаємодією, взаємопроникненням та взаємозамінним характером складових частин, які забезпечують іiі якість, а саме: 1) мотиваційна мобільність, що представляє собою динамічну готовність до реалізації власних можливостей у різних функціональних видах діяльності (інструменталіствиконавець, концертмейстер); 2) інтелектуальна мобільність - це спосіб орієнтуватися в творчому музичному просторі, гнучкість мислення, які дозволяють знаходити нестандартні рішення, творча ініціатива; 3) емоційно-вольова мобільність представляє собою динамічне вміння здійснювати адекватну самооцінку, самоконтроль, 
самодіагностику, аналіз результатів власної виконавської діяльності, керування своїм психічним станом; 4) ригідна мобільність характеризує легкість пристосування особистості до ситуації, що змінюється, легкість зміни установок та суджень; 5) інтерпретаційна мобільність розглядається як здатність до динамічної, спонтанної інтерпретації музичного твору, що відрізняється від точного слідування тексту, який був написаний раніше; 6) особистісна мобільність представляє собою цілеспрямовану активність особистості із саморозвитку та самовдосконалення.

Тому, виконавська мобільність формує здатність до варіативності зміни ходу та змісту виконавської діяльності, дозволяє гнучко долати ії труднощі та «штампи», легко та швидко приймати рішення в швидкоплинних творчих ситуаціях, здійснювати вибір найбільш вдалого з професійної точки зору рішення поставлених творчих завдань.

У контексті вивчення феномену виконавської мобільності педагога-музиканта визначимо її структурні складові, в основу яких покладено принцип цілісного поєднання компонентів. Додамо, що у філософській літературі структуру тлумачать як засіб закономірного зв’язку між складовими предметів і явищ природи і суспільства, мислення і пізнання; як сукупність істотних зав’язків виділених частин цілого, що забезпечує його єдність [3, с. 978].

Виокремимо ключові (опорні) слова, які охоплюють поняття «мобільність» як систему. Отже розглянемо їх послідовно: 1) інформаційно-потребнісний компонент: передбачає потребу у досконалому оволодінні виконавською діяльністю, реалізується в цілому у прагненні майбутнього педагога-музиканта до самовдосконалення у професійній діяльності, а також до реалізації власного виконавського творчого потенціалу в умовах конкурсних змагань і публічних виступів; 2) операційнотехнологічний компонент: інструментально-виконавські уміння та навички, з однієї сторони, та сукупність якостей особистості, які дозволяють успішно здійснювати професійну діяльність, 3 іншої, формують інтегрований показник професійної майстерності музиканта. Рівень інструментально-виконавської майстерності залежить від технічних засобів (умінь і навичок) музиканта для гри на інструменті, емоційновольових якостей та індивідуально-типологічних властивостей (характер, здібності, темперамент) конкретного музиканта. 3) Емоційно-оцінний компонент: осягнення емоційно-образного змісту твору здійснюється завдяки реалізації двох задач, де перша 
3 них - інтелектуальна - полягає у тому, щоб зрозуміти та усвідомити задум композитора. Реалізація цієї задачі повинна трансформуватись у сферу наступної емоційної задачі, яка характеризується емоційними переживаннями авторського задуму, що реалізує музикант-інструменталіст, виражаючи таким чином своє емоційне ставлення до музичного твору. Можливість музиканта виражати у музичному творі багатогранність емоційних хвилювань залежить від його внутрішніх здатностей генерувати у своїй психіці переживання.

4) Творчо-комунікативний компонент: володіння навичками соціокультурної комунікації, що дозволяє музиканту-інструменталісту швидше та 3 мінімальними психофізичними витратами включитись у професійний процес взаємодії з партнерамимузикантами зі спільної виконавської діяльності та різними категоріями слухачів, досягати злагодженості виконавських дій, створювати позитивний емоційний клімат у творчому колективі, що в кінцевому результаті, повинно додати динамізму та ефективності виконавській діяльності. Наполегливість, ініціативність, самостійність, витримка та саморегуляція, сміливість та рішучість - всі ці риси поведінки по-різному проявляються в діяльності музиканта.

Викладене вище, ще раз засвідчує, що специфіка професійної підготовки майбутнього вчителя музики визначається необхідністю інтегрованої взаємодії елементів, що входять в поняття «вчитель» та поняття «музикант». Багатопланова діяльність вчителя музики передбачає синтез вказаних понять, які формують професійні засади його підготовки, на базі психолого-педагогічних та фахових знань та умінь.

Висновки. Отже, проведений структурно-функціональний аналіз виконавської мобільності майбутнього вчителя музики уможливив пояснення сутності та специфіки iii компонентів, а також доводить, що в практичній діяльності педагога-музиканта усі вищезазначені компоненти синтезовані, створюють єдину систему, спрямовану на цілісне формування досліджуваного феномену у майбутніх вчителів музики вищих на художньо-педагогічних закладів освіти.

Розглянуті шляхи формування виконавської мобільності майбутнього педагогамузиканта, екстраполюючись у площину фортепіанної підготовки майбутніх учителів музики, дали змогу виокремити специфічні особливості означеної підготовки, які, в першу чергу, полягають у іï педагогічній спрямованості. Педагогічно спрямована 
фортепіанна підготовка формує знання, уміння та емоційні компетенції, необхідні для умов педагогічної діяльності, що стрімко змінюються. Це уможливлює формування здатності майбутнього педагога-музиканта швидше входити до професійного музичного середовища, набуваючи професійний досвід та оволодіваючи його стандартами та цінностями.

Нами описано складові виконавської мобільності, які характеризують різноманітність функцій та умінь майбутнього учителя музики, а проведений аналіз дозволив сформулювати поняття «виконавська мобільність» майбутнього учителя музики як інтегративний, динамічний показник, щуо характеризує здатність до варіативних змін в процесі виконавської діяльності з метою найбільш вдалого вирішення ситуаційних виконавських проблем.

Подальше вивчення виконавської мобільності майбутнього учителя музики передбачає змістовно-структурний аналіз даного феномену.

\section{References}

1. Archazhnikova L. G. Teoreticheskie osnovy professionalno-pedagogicheskoj podgotovki uchitelya muzyki [Theoretikal foundations of professionally-pedagogic treining of teachers of music]: diss. doktora ped.nauk: 13.00.0. Moscow,1986. 505 p.

2. Blanko O. M. Vikonavska mobilnist yak chinnik rozvitku suchasnoyi kamernoyi vokaknoyi muziki [Performing mobility as a factor in the development of modern chamber vokal music]. Mistetstvoznavski zapiski: zb. nauk. statey. Kyiv: Milenium, 2016. Issue 29. P.74-83.

3. Istoriya filosofii. Entsiklopeliya [History of philosophy. Encyclopedia] /compiled by Gritsanov A.A. Minsk: Knizhnyiy dom, 2002. 1376 p.

4. Padalka Gh. M.Pedaghoghika mystectva (Teorija $i$ metodyka vykladannja mystecjkykh dyscyplin) [Art pedagogics (Theory and methodology of teaching art courses)]. Kyiv: Osvita Ukrajiny, 2008. 274 p.

5. Pet'ko L.V. Robota nad pisneju v kursi anglijs'koi' movy jak odyn iz zasobiv profesijnoi' pidgotovky studentiv gumanitarnyh special'nostej VNZ [The song in English course as a means of training humanities majors university students']. Inozemni movy. 2011. No. 1. P. 44-48.

6. Pet'ko L.V. Formuvannya profesiyno orientovanogo inshomovnogo navchalnogo seredovishcha v umovah universitetu dlya studentiv spetsialnosti «Muzichne mistetstvo» (na prikladi virsha Meri Hovitt «Pavuk i Muha») [Formation of professionally oriented foreign language teaching environment in the terms of university for students of Music Art specialty (on illustration of a poem «The Spider and the Fly» by Mary Howitt)] Naukovi zapiski Berdyanskogo derzhavnogo pedagogichnogo universitetu. Pedagogichni nauki: zb. nauk. pr. Issue 1. Berdyansk : FO-P Tkachuk O.V., 2016. P. 184-190. 
7. Sizova E. Z. Kommunikativnaya kultura kak faktor povysheniya kachestva professionalnoj podgotovki studentov muzykalnogo kolledzha [Communicative culture as a factor of improving the quality in vocational training of students at a musical college. Srednee professionalnoe obrazvanie. 2007. No. 12. P. 44-46.

8. Teoriya i metodika mistetskoyi osviti.Naukova shkola G.M.Padalki [ Theory and methodology of art education. Scientific school G.M.Padalki] : kolektivna monografiya /nauk.red. A.V. Kozir. Kyiv : NPU im.Dragomanova, 2010. 360 p.

9. Fedorovich E. N. Osnovy muzykalnoj psikhologii [Basics of music psychology] : ucheb. posobie. Ekaterinburg, 2007. 206 p.

10. Shcholokova O. P. Osnovni tendentsiyi fortepiannoyi diyal'nosti pedahohichnomuzychnoyi tvorchosti u inshykh muzychnykh navchal'nykh zakladakh [Major trends of piano activity of pedagogical and musical creativity in other musical educational establishments] // Topical issues of education: collective monograph. Lisbon, Portugal : Pegasus Publishing, 2018. P. 205--219.

11. Yaranceva N.YA. Khudozhestvennaya deyatelnost. Problemy subekta i obekta determinatsii [Art activity. Problems of subject and object of determination]. Kyiv: Naukova dumka. $244 \mathrm{p}$.

12. Pet'ko L. V. Formation of professionally oriented foreign language teaching environment in the conditions of university for students of specialties 023 «Fine Arts» and 022 «Design» // Economics, management, law:realities and perspectives: Collection of scientific articles. Psychology. Pedagogy and Education. - Les Editions L'Originale, Paris, France. 2016. P. 466-470.

13. Pet'ko L. V. Formation of professionally oriented foreign language teaching environment in the conditions of university for students of art specialties // Economics, management, law: problems of establishing and transformation: Collection of scientific articles. - Al-Ghurair Printing \& Publishing LLC, Dubai, UAE, 2016. P. 395-398.

14. Shcholokova O. P. Art and pedagogical designing as a means of improvement of music teacher's professional preparing // Economics, management, law: socio-economical aspects of development: Collection of scientific articles. Volum 2. - Edizioni Magi - Roma, Italy. 2016. P. 265-268.

15. Shcholokova Olga. Modern Views on the problem Piano tone production in the musicalpedagogical literature / Olga Shcholokova, Wang Xue // Intellectual Archive. Toronto : Shiny Word.Corp. (Canada). 2016. November/December. Vol. 5. No. 6. PP. 81-90.

Translation of the Title, Abstract and References to the Author's Language

УДК378.011.3-/05/:78\}:7.071.3

Калішук О. Д. Розгляд виконавської майстерності майбутнього вчителя музики в аспекті формування його виконавської мобільності.

Розглянуто актуальні питання підвищення рівня виконавської майстерності майбутнього учителя музики в аспекті формування його виконавської мобільності. Представлено специфіку інструментальної підготовки студентів даного профілю та проаналізовано різні наукові погляди щодо їх професійної компетентності як педагога 
та музиканта. Розкрито сутність особливості виконавської мобільності студентівпіаністів; описано структурний аналіз іiі компонентів: інформаційно-потребнісного, операційно-технологічного, емоційно-оцінного та соціально-комунікативного. Визначено поняття виконавської компетентності та виконавської діяльності. Досліджені здібності учителя музики, що забезпечують його здатність до виконавської мобільності.

Ключові слова: майбутній вчитель музики, виконавська мобільність, компоненти виконавської мобільності.

\section{Література}

1. Арчажникова Л. Г. Теоретические основы профессионально-педагогической подготовки учителя музыки: дисс. ... д-ра пед. наук: 13.00.01. Москва 1986. 505 с.

2. Бланко О. М. Виконавська майстерність як чинник розвитку сучасної камерної вокальної музики. Мистецтвознавчі записки. Київ: Milenium, 2016. Вип. 29. Р. 74-83.

3. Історія філософії : Енциклопедія . Москва : Книжковий дім, 2002.

4. Падалка Г.М. Педагогіка мистецтва (Теорія і методика викладання мистецьких дисциплін) : [монографія]. Київ: Освіта України, 2008. 274 с.

5. Петько Л. В. Робота над піснею в курсі англійської мови як один із засобів професійної підготовки студентів гуманітарних спеціальностей ВНЗ. Іноземні мови. 2011. № 1. С. 44-48.

6. Петько Л. В. Формування професійно орієнтованого іншомовного навчального середовища в умовах університету для студентів спеціальності «Музичне мистецтво» (на прикладі вірша Мері Ховітт «Павук і Муха»). Наукові записки Бердянського державного педагогічного університету. Педагогічні науки: зб. наук. пр. Вип. 1. Бердянськ : ФО-П Ткачук О.В., 2016. 184-190.

7. Сизова Е. 3. Коммуникативная культура как фактор повышения качества профессиональной подготовки студентов музыкального колледжа. Среднее профессиональное образование. 2007. № 12. С. 44-46.

8 Теорія і методика мистецької освіти. Наукова школа Г.М.Падалки : колективна монографія / наук. ред. А. В. Козир. Київ : Вид-во НПУ імені Н. П. Драгоманова , 2010. $360 \mathrm{c}$.

9. Федорович Е. Н., Тихонова Е. В. Основи музикальной психологии : учеб. пособие. Екатеринбург, 2007. 206 с.

10. Щолокова О. П. Основні тенденції фортепіанної підготовки педагогамузиканта у вищих мистецьких закладах освіти // Topical issues of education : collective monograph. - Lisbon, Portugal : Pegasus Publishing, 2018. Р. 205-219.

11. Яранцева Н. Я. Художественная деятельность. Проблемы субъекта и объекта детерминации . Київ: Наукова думка. 1980. 244 с.

12. Pet'ko L. V. Formation of professionally oriented foreign language teaching environment in the conditions of university for students of specialties 023 «Fine Arts» and 022 «Design»// Economics, management, law:realities and perspectives: Collection of scientific articles. Psychology. Pedagogy and Education. - Les Editions L'Originale, Paris, France. 2016. P. 466-470.

13. Pet'ko L. V. Formation of professionally oriented foreign language teaching environment in the conditions of university for students of art specialties // Economics, 
management, law: problems of establishing and transformation: Collection of scientific articles. - Al-Ghurair Printing \& Publishing LLC, Dubai, UAE, 2016. P. 395-398.

14. Shcholokova O. P. Art and pedagogical designing as a means of improvement of music teacher's professional preparing // Economics, management, law: socio-economical aspects of development: Collection of scientific articles. Volum 2. - Edizioni Magi Roma, Italy. 2016. P. 265-268.

15. Shcholokova Olga. Modern Views on the problem Piano tone production in the musical pedagogical literature / Olga Shcholokova, Wang Xue // Intellectual Archive. Toronto : Shiny Word.Corp. (Canada). 2016. November/December. Vol. 5. No. 6. PP. 81-90. 